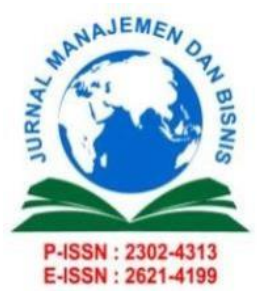

Jurnal Manajemen dan Bisnis

Vol. 10, No. 2, December 2021, pp. 137-154

Sekolah Tinggi Ilmu Ekonomi Indragiri (STIE-I) Rengat

https://journal.stieindragiri.ac.id/index.php/imbi/issue/view/20

\title{
THE EFFECT OF POST TSUNAMI HOTEL TAX RECEIVING AND PARKING TAX ON ORIGINAL LOCAL REVENUE (PAD) PANDEGLANG REGENCY PERIOD 2015-2019
}

\author{
Refi Pratiwi ${ }^{1)}$ Tri Wahyudi² \\ 1) 2) Akuntansi, Universitas Sultan Ageng Tirtayasa \\ refipratiwi9112@yahoo.com ${ }^{1}$, tri.wahyudi@untirta.ac.id $^{2)}$ \\ Submited: 2021.09.02 Reviewed: 2021.11.20 Accepted: 2021.12.31 \\ https://doi.org/10.34006/imbi.v10i2.297
}

\begin{abstract}
The Pandeglang Regency Local Tax Service (BP2D), which is in accordance with its authority as the coordinator of hotel tax collection and parking tax, is one of the Local Revenues. One indicator that reflects the independence and success of a region is the receipt of Original Local Revenue (PAD). The purpose of this study was to determine the effect of hotel tax receipts on Original Local Revenue (PAD), to assess the impact of parking tax receipts on Original Local Revenue (PAD), and to determine the effect of hotel tax receipts and parking taxes simultaneously on Original Local Revenue (PAD). ) at Pandeglang Regency 2015-2019. This research was designed using a quantitative research approach. The data collection technique used was secondary data. The research was conducted at The Pandeglang Regency Local Tax Service Agency (BP2D). The sample of this research is the 2015-2019 Pandeglang Regency budget report. The results of this study are hypothesis 1 there is no effect of hotel tax receipts on Original Local Revenue (PAD), hypothesis 2 there is no effect of parking tax receipts on Original Local Revenue (PAD), and hypothesis 3 does not influence hotel tax receipts and parking taxes simultaneously on Original Local Revenue (PAD) at Pandeglang Regency 2015-2019.
\end{abstract}

Keywords: Hotel Tax and Original Local Revenue (PAD), Parking Tax

\section{INTRODUCTION}

The Tsunami that hit the Sunda Strait, quite a lot of hotels and parking facilities were damaged, it was recorded that the Tourism Crisis Center (TCC) of the Ministry of Tourism 69 hotels were damaged due to the brunt of the Tsunami in 2018, precisely on December 22. The Sunda Strait is deserted, and tourism is reduced, resulting in a decrease in Local Revenue.

One source of state revenue is taxes. Taxes for local government act as the main source of income (budgetary function) and also as a regulatory function. One of local financing is taxes from Local Revenue used to finance government expenditures, provide education and health facilities, finance government administration, build and repair 
infrastructure, finance police officers, and finance local government activities in providing needs for the State. The importance of taxes for a local and one of the sources of Local Revenue, which is the main in helping local construction itself, is a very potential funding income because the amount of tax revenue will increase population growth, improve the economy, and become political stability, taxes are the most important thing for local construction.(Alisman, 2015)

Local autonomy provides space for local creativity to find sources of Local Revenue that can finance local government expenditures in the context of administering government and development. In-Law Number 28 of 2009 concerning local tax and local retribution, local tax, and local retribution are two sources of Original Local Revenue (PAD). Reflecting the high level of Original Local Revenue (PAD) is the result of the success of these businesses and the level of local ability level in government financing and development.

Law No. 34 of 2000 concerning local tax and local retribution, which has been declared no longer valid with the existence of Law No. 28 of 2009, including the types of district or city taxes are as follows: Hotel, Restaurant, Entertainment, Advertising Tax, Street Lighting, Extraction of Class C Excavated Materials, Parking, Urban and Rural Land and Building Tax, Land and Building Acquisition Fees, Swallow's Nest Tax, Tax on Extraction and Utilization of Groundwater.

The existence of a Local Autonomy policy that focuses on districts and cities to develop locally becomes a challenge for regencies and cities to build locally. The hope is that the community can feel the facilities built by local government, Law Number 28 of 2009 articles 31 and 32, parking tax is a tax on the operation of parking spaces outside the road body, both those provided in connection with the main business and those provided as a business, including the provision of a place for storing motorized vehicles, while what is meant by Parking is the immovable State of a vehicle that is not temporary. The amount of parking and hotel tax rates is set in the Regency or City in Banten Province according to the respective local regulations that have been set.(Pratama et al., 2017)

Pandeglang's original local revenue (PAD) for the 2015-2019 period, revenue from the hotel tax sector has not been able to provide a maximum contribution in increasing original local revenue (PAD), because hotels in several Pandeglang areas were affected by the Tsunami so that hotel business revenues decreased.

Tabel 1. Original Local Revenue (PAD) And Tax Revenue

\begin{tabular}{rrrr}
\hline Year & \multicolumn{1}{c}{ Realized PAD } & \multicolumn{1}{l}{ Hotel Tax } & \multicolumn{1}{c}{ Parking Tax } \\
\hline 2015 & $30,015,140,492$ & $2,843,148,211$ & $56,295,437$ \\
2016 & $34,231,832,124$ & $3,245,162,780$ & $41,491,434$ \\
2017 & $78,645,728,341$ & $3,575,068,943$ & $52,788,455$ \\
2018 & $48,249,929,834$ & $3,495,538,095$ & $77,553,697.00$ \\
2019 & 54.700 .151 .490 & Target & Target \\
& & $3,974,420,000$ & $145,836,338$ \\
\hline
\end{tabular}

Source: BP2D Pandeglang Regency website (2021)

Efforts to optimize hotel tax revenues and regional parking taxes require control from interested parties, namely the Pandeglang Regional Tax Service Agency (BP2D), which is in accordance with its authority as the coordinator of hotel tax collection and parking tax, one of which is regional revenue. One indicator that reflects the independence and success of a region is the receipt of original local revenue (PAD). 
This is where The Regional Tax Service Agency must overcome and seek programs or ways to increase Regional Original Income both in terms of local retribution and local tax so that they always meet targets and achieve their realization because Regencies and Cities in Banten Province have the potential for Regional Original Income both in terms of local tax and local retribution.

The change in regional revenue targets was caused by several factors, including the adjustment of revenue targets from PAD after considering rationally measured estimates that can be achieved for each source of regional income and PAD realization up to the first semester of 2015.

Hotel tax revenues and regional parking taxes must be optimized; it is necessary to control the parties concerned, namely the Regency and City Regional Revenue and Financial Management Offices in Banten Province, which are in accordance with their functions as coordinators of hotel tax collection and parking taxes, one of which is regional financial revenue. One of the indicators that determine the degree of independence of a region is the revenue from its own regional revenue (PAD).

The purpose of this study was to determine the effect of hotel tax revenue on Regional Original Revenue, to assess the impact of parking tax receipts on Regional Original Revenue, and to assess the impact of hotel tax receipts and parking taxes simultaneously on Regional Original Revenues in Pandeglang 2015-2019.

\section{REVIEW OF LITERATURE}

According to Mardiasmo (2013:12), local tax is a contribution made by an individual or entity to the Region without a balanced direct reward, which can be imposed based on the applicable laws and regulations, which is used to finance the administration of local government. Local tax is a tax whose management is handled by the local government, in this case, the regional head, governor, mayor, regent. Local taxes are distinguished according to those who manage them, namely Provincial Taxes and Regency/City Taxes.

Based on regional regulations in accordance with applicable laws and regulations, original local revenue (PAD) is all revenues obtained by the Region from sources collected within its own territory. In the regional income sector, besides playing a significant role, this sector reflects the independence and success of the Region.

The regional income sector plays a significant role because through this sector, it can be seen how far a region can finance government activities and regional development.

Based on the definition of original local revenue (PAD) put forward by several experts above, basically, they have almost the same characteristics. So it can be concluded that original local revenue (PAD) is all local revenue sourced from local taxes, local retribution, the results of separated regional wealth management, and other legitimate original local revenue (PAD).

According to Law No. 33 of 2004 concerning Financial Balance between the Central Government and Regional Governments divides original local revenue (PAD) into three parts, namely:

1. Original local revenue (PAD) comes from:

a. local tax

Local tax is one of the incomes that contributes a lot to the original local revenue (PAD). Tax is a mandatory payment imposed by law.

b. local retribution

Local retribution is a mandatory payment from residents to the State arising from certain services provided by the State for its residents individually. 
c. The results of the management of separated regional assets

Regional revenue receipts other than local taxes and local retribution are the management of separated regional assets, which in this case includes profits from BUMD and the results of local government collaboration with third parties.

d. Other valid PAD

2. Balancing Fund

Funds sourced from APBN revenues allocated by regional heads to fund regional needs in the context of implementing decentralization

3. Other legitimate regional income

The last regional revenue is through legitimate regional income, where the payment includes:

1) The proceeds from the sale of regional assets that are not separated

2) Current Account

3) Interest income

4) Gain on the difference in the exchange rate of the rupiah against foreign currencies

5) Commissions, discounts, or other forms as a result of sales and services by the Region.

Hotel tax is a tax levied on services that provide convenience, including sports and entertainment facilities. Hotels are provided, including supporting services as a complete hotel. ${ }^{1}$

The object of hotel tax is the service with payment provided by the hotel, including hotel services and amenities that provide convenience and comfort, including sports and entertainment facilities which are included in, there are several types of lodging facilities or in the form of short-term or long-term stay facilities including places to stay. Boarding houses, guesthouses, tourist lodges, and conference halls.(Irwan, 2015)

Based on the above definition, it is concluded that hotel tax is a tax on services and facilities provided by hotels to support comfort and convenience.

The legal basis for collecting Hotel Tax is as follows:

1. Law Number 28 of 2009 concerning local taxe and local retribution.

2. Law Number 34 of 2000 is an amendment to Law Number 18 of 1997 concerning local taxes and local retribution.

3. Government Regulation Number 65 of 2001 concerning local taxes.

4. Regency/City regional regulations are governing Hotel Tax (specifically for Palembang City, namely Regional Regulation Number 11 of 2010 (Hotel Tax).

5. The decision of the regent/mayor that regulates the Hotel Tax as a rule for implementing the Regional Regulation on Hotel Tax in the said Regency/City.

Hotel Tax Objects are services provided by hotels with payment, including facilities to support hotel completeness which aims to provide convenience and comfort, including sports and entertainment facilities. Supporting services as a complete hotel are a telephone, facsimile, internet, and other similar facilities provided or managed by the hotel.

In the imposition of Hotel Tax into tax objects including services, namely:

1. Lodging facilities or short-term stay facilities. In terms of lodging houses, lodging houses include boarding homes with ten or more rooms that provide facilities such as lodging houses.

2. Supporting services as the completeness of lodging facilities or short-term residences that provide convenience and comfort.

3. Sports and entertainment facilities are explicitly provided for hotel guests.

\footnotetext{
${ }^{1}$ Wisanggeni Irwan, Taxes in Various Business Sectors. (Jakarta: Index Publisher, 2015), p.16
} 
4. Room rental services for events or meetings at the hotel.

Basis of imposition and hotel tax rates According, Basic Tax Imposition (DPP) is the amount of payment or that should be paid to the hotel, including boarding houses, guesthouses, tourist lodges, and meeting buildings. According to Waluyo $(2011,240)$, the Hotel Tax Rate is set at a maximum of $10 \%$ (ten percent) which is determined by Regional Regulations and the Basis of Tax Imposition, namely the amount of payment that should be paid to the hotel.(Samudra, 2015)

In accordance with the mandate of Law Number 28 of 2009 concerning local taxe and local retribution, Government Regulation Number 55 of 2016 concerning General Provisions and Procedures for Collection of Local Taxes and Regional Regulation Number 3 of 2018 concerning Second Amendment to Regional Regulation Number 1 of 2011 concerning Local Taxes, We need to convey the provisions regarding the Imposition of Parking Tax as a local tax as follows. Parking is a temporary state of immobility of a vehicle. (2) Parking Tax is a tax on the operation of off-street parking spaces, whether provided in connection with the main business or provided as a business, including the provision of a place for storing motorized vehicles. (3) In the event that the parking lot operator does not collect parking rental from the parking service recipient, the basis for imposition of parking tax is calculated by taking into account the parking area, the average number of vehicles parked every day, the number of operational days for the parking lot in 1 (one) month.

So it can be concluded that according to the above definition law, parking tax is a tax imposed on individuals or legal entities that carry out parking activities in their business as well as the provision of motorized vehicle storage places that collect fees.

According to the status of parking taxes are classified into five types:(Liberty, 2014)

1. Public Parking

Public Parking is a particular place that has a function as Parking for a vehicle where the provider of the parking space is the local government that uses land, roads, and fields controlled by the local government.

2. Dedicated Parking

Special Parking is a parking space that is provided and managed by a 3 (three) party using controlled lands.

3. Emergency Parking

Emergency parking is a public place used for incentive activities by the local government or the private sector by using land, roads, and fields owned by the government.

4. Parking Park

Parking Park is a parking area that is managed and organized by the local government and has been equipped with parking facilities and facilities

5. Parking Building

A parking building is a parking lot organized by the regional government or a 3rd party (three) who obtains a special permit in a building as a parking space.

The object of the Parking Tax is the operation of off-street parking spaces, whether provided in connection with the main business or provided as a business, including the provision of a place for storing motorized vehicles.

In Article 62 paragraph (2), Law No. 28 of 2009 concerning local taxes and local retribution, which are not included in the tax object as referred to in paragraph (1), are:

a. Implementation of parking lots by the Government and Regional Governments;

b. Organizing parking lots by offices that are only used for their own employees;

c. Organizing parking lots by embassies, consulates, and representatives of foreign countries on the principle of reciprocity;

d. Organizing storage of motorized vehicles with a capacity of up to 10 (ten) or more 4 
(four) wheeled vehicles and a total of up to 20 (twenty) 2 (two) wheeled vehicles;

e. The operation of parking lots that are solely used for the business of motorized trading vehicles.

In Article 63 paragraph (1), Law No. 28 of 2009 concerning local taxes and local retribution, namely the subject of the Parking Tax is an individual or entity that parks a motorized vehicle.

The amount of the parking tax rate is determined in accordance with Law No. 28 of 2009 concerning local taxe and local retribution, which is a maximum of thirty percent (30\%); the aim is to provide flexibility to local governments to set parking tax rates because each city or district to determining the number of tax rates may vary, as long as it does not exceed the set target (30\%).(Puspitasari et al., 2016)

\section{Relevant research}

The following are the results of relevant research used in this study are as follows:

Table 2.1 Relevant Research Results

\begin{tabular}{|c|c|c|c|c|c|c|}
\hline No & $\begin{array}{l}\text { Name \& } \\
\text { Year }\end{array}$ & Research Title & $\begin{array}{l}\text { Name of } \\
\text { Institution }\end{array}$ & $\begin{array}{l}\text { Research } \\
\text { methods }\end{array}$ & $\begin{array}{l}\text { Research } \\
\text { result }\end{array}$ & $\begin{array}{l}\text { Differences in } \\
\text { the research to } \\
\text { be carried out }\end{array}$ \\
\hline 1 & $\begin{array}{c}\text { Saad Syaus and } \\
\text { Dharmawaty S. } \\
\text { Makur } \\
(2019)\end{array}$ & $\begin{array}{l}\text { The Effect of } \\
\text { Parking Tax on } \\
\text { Original Local } \\
\text { Revenue (PAD) } \\
\text { in Gorontalo }\end{array}$ & $\begin{array}{c}\text { Muhammadi } \\
\text { yah } \\
\text { University of } \\
\text { Gorontalo }\end{array}$ & $\begin{array}{c}\text { Quantitative } \\
\text { descriptive }\end{array}$ & $\begin{array}{l}\text { Parking tax } \\
\text { has a } \\
\text { significant } \\
\text { effect on } \\
\text { original } \\
\text { local } \\
\text { revenue } \\
\text { (PAD) }\end{array}$ & $\begin{array}{c}\text { Hotel Tax } \\
\text { Research } \\
\text { where the } \\
\text { research is } \\
\text { located in } 8 \\
\text { regencies/cities } \\
\text { throughout the } \\
\text { province of } \\
\text { Banten }\end{array}$ \\
\hline 2 & $\begin{array}{c}\text { Arnida } \\
\text { Wahyuni and } \\
\text { Rinie Utara } \\
(2018)\end{array}$ & $\begin{array}{l}\text { The Effect of } \\
\text { Hotel Tax } \\
\text { Revenue and } \\
\text { Restaurant Tax } \\
\text { on Original } \\
\text { Local Revenue } \\
\text { (PAD) on Local } \\
\text { Tax and Local } \\
\text { Retribution } \\
\text { Service Agency } \\
\text { in Medan }\end{array}$ & $\begin{array}{c}\text { North } \\
\text { Sumatra } \\
\text { State } \\
\text { Islamic } \\
\text { University }\end{array}$ & $\begin{array}{c}\text { Quantitative } \\
\text { descriptive }\end{array}$ & $\begin{array}{l}\text { Hotel tax } \\
\text { has a } \\
\text { positive } \\
\text { and } \\
\text { significant } \\
\text { effect on } \\
\text { original } \\
\text { local } \\
\text { revenue } \\
\text { (PAD) }\end{array}$ & $\begin{array}{l}\text { Hotel Tax } \\
\text { Research } \\
\text { where the } \\
\text { research is } \\
\text { located in } 8 \\
\text { regencies/citie } \\
\text { s throughout } \\
\text { the province } \\
\text { of Banten }\end{array}$ \\
\hline 3 & $\begin{array}{l}\text { Ridho Pratama, } \\
\text { Ernadhi } \\
\text { Sudarmanto, and } \\
\text { Tiara Timuriana } \\
\text { (2018) }\end{array}$ & $\begin{array}{c}\text { The Effect of } \\
\text { Parking Tax } \\
\text { Revenue on } \\
\text { original local } \\
\text { revenue (PAD) } \\
\text { in Bogor 2014- } \\
2017\end{array}$ & $\begin{array}{c}\text { Pakuan } \\
\text { University }\end{array}$ & $\begin{array}{l}\text { Quantitative } \\
\text { descriptive }\end{array}$ & $\begin{array}{l}\text { Parking tax } \\
\text { has an effect } \\
\text { on original } \\
\text { local revenue } \\
\text { (PAD) }\end{array}$ & $\begin{array}{c}\text { Hotel Tax } \\
\text { Research } \\
\text { where the } \\
\text { research is } \\
\text { located in } 8 \\
\text { regencies/cities } \\
\text { throughout the } \\
\text { province of } \\
\text { Banten }\end{array}$ \\
\hline 4 & $\begin{array}{l}\text { Wahyu Indro } \\
\text { Widodo and } \\
\text { Bambang } \\
\text { Guritno (2017) }\end{array}$ & $\begin{array}{c}\text { The Effect of } \\
\text { Hotel Tax, } \\
\text { Restaurant Tax } \\
\text { and Entertainment } \\
\text { Tax on Original } \\
\text { Local Revenue } \\
\text { (PAD) in } \\
\text { Yogyakarta }\end{array}$ & $\begin{array}{c}\text { Indonesian } \\
\text { College of } \\
\text { Tourism } \\
\text { Economics } \\
\text { Semarang }\end{array}$ & $\begin{array}{l}\text { Quantitative } \\
\text { descriptive }\end{array}$ & $\begin{array}{l}\text { Hotel tax has } \\
\text { a significant } \\
\text { effect on } \\
\text { original local } \\
\text { revenue } \\
\text { (PAD) }\end{array}$ & $\begin{array}{l}\text { Parking tax } \\
\text { research sites in } \\
8 \\
\text { regencies/cities } \\
\text { throughout the } \\
\text { province of } \\
\text { Banten }\end{array}$ \\
\hline
\end{tabular}




\begin{tabular}{|c|c|c|c|c|c|c|}
\hline No & $\begin{array}{l}\text { Name \& } \\
\text { Year }\end{array}$ & Research Title & $\begin{array}{l}\text { Name of } \\
\text { Institution }\end{array}$ & $\begin{array}{l}\text { Research } \\
\text { methods }\end{array}$ & $\begin{array}{l}\text { Research } \\
\text { result }\end{array}$ & $\begin{array}{l}\text { Differences in } \\
\text { the research to } \\
\text { be carried out }\end{array}$ \\
\hline 5 & $\begin{array}{l}\text { Aznedra } \\
(2017)\end{array}$ & $\begin{array}{c}\text { The Effect of } \\
\text { Contribution of } \\
\text { Hotel Tax } \\
\text { Revenue and } \\
\text { Restaurant Tax on } \\
\text { Original Local } \\
\text { Revenue (PAD) in } \\
\text { Batam City } \\
\text { Region in 2012- } \\
\text { 2014 (Case Study } \\
\text { of Original Local } \\
\text { Revenue (PAD) } \\
\text { Service in Batam) }\end{array}$ & $\begin{array}{l}\text { Kepulauan } \\
\quad \text { Riau } \\
\text { University }\end{array}$ & $\begin{array}{l}\text { Quantitative } \\
\text { descriptive }\end{array}$ & $\begin{array}{l}\text { Hotel tax has } \\
\text { no } \\
\text { significant } \\
\text { effect on } \\
\text { original local } \\
\text { revenue } \\
\text { (PAD) }\end{array}$ & $\begin{array}{l}\text { Parking tax } \\
\text { research sites in } \\
8 \\
\text { regencies/cities } \\
\text { throughout the } \\
\text { province of } \\
\text { Banten }\end{array}$ \\
\hline 6 & $\begin{array}{l}\text { Asma Mufidah, } \\
\text { Jeni Susyanti, } \\
\text { and Afi Rachmat } \\
\text { Slamet } \\
(2017)\end{array}$ & $\begin{array}{l}\text { Analysis of the } \\
\text { Effect of Parking } \\
\text { Tax, Restaurant } \\
\text { Tax and local } \\
\text { parking retribution } \\
\text { on original local } \\
\text { revenue (PAD) in } \\
\text { Malang } \\
\text { (Case Study of } \\
\text { Regional Financial } \\
\text { and Asset } \\
\text { Management } \\
\text { Agency in } \\
\text { Malang) }\end{array}$ & $\begin{array}{c}\text { Faculty of } \\
\text { Economics } \\
\text { Unisma }\end{array}$ & $\begin{array}{l}\text { Quantitative } \\
\text { descriptive }\end{array}$ & $\begin{array}{l}\text { Parking tax } \\
\text { has a } \\
\text { significant } \\
\text { effect on } \\
\text { original local } \\
\text { revenue } \\
\text { (PAD) }\end{array}$ & $\begin{array}{l}\text { Variable tax on } \\
\text { hotel research } \\
\text { in } 8 \\
\text { regencies/cities } \\
\text { in Banten } \\
\text { province }\end{array}$ \\
\hline 7 & $\begin{array}{l}\text { Engi Sandi } \\
\text { Utami } \\
(2015)\end{array}$ & $\begin{array}{l}\text { The Effect of } \\
\text { Restaurant and } \\
\text { Hotel Taxes on } \\
\text { Original Local } \\
\text { Revenue (PAD) } \\
\text { in Bandung } \\
(2009-2013)\end{array}$ & $\begin{array}{c}\text { Telkom } \\
\text { University }\end{array}$ & $\begin{array}{c}\text { Quantitativ } \\
\mathrm{e} \\
\text { descriptive }\end{array}$ & $\begin{array}{l}\text { Hotel tax } \\
\text { has a } \\
\text { significant } \\
\text { effect on } \\
\text { original } \\
\text { local } \\
\text { revenue } \\
\text { (PAD) }\end{array}$ & $\begin{array}{l}\text { Variable } \\
\text { Parking tax at } \\
\text { the research } \\
\text { sites in } 8 \\
\text { districts/cities } \\
\text { throughout the } \\
\text { province of } \\
\text { Banten }\end{array}$ \\
\hline
\end{tabular}

Source: Processed data

\section{Hypothesis Development}

The effect of hotel tax revenues on original local revenue (PAD) and original local revenue (PAD) in addition to increasing the financing capacity of local governments as well as reducing regional dependence on the center. Efforts to increase original local revenue (PAD) can be achieved by optimizing original local revenue (PAD) through improving the performance of the PAD levy management apparatus as well as applying the technical aspects of collecting proportionally and professionally. One type of local tax is hotel tax.

The results show that hotel tax has a positive relationship and has a significant effect on Padang City's original local revenue (PAD). Therefore, with the increase in local taxes sourced from hotel taxes, the original local revenue (PAD) will also increase. (Wahyuni dan Utara, 2018)

Therefore, the hypothesis proposed is

Hypothesis 1: It is suspected that hotel tax receipts partially affect the original local revenue (PAD) of Pandeglang Regency for the 2015-2019 period

The Effect of Parking Tax on Original Local Revenue (PAD) According to the 
Director-General of Taxes (DJP), Original Local Revenue (PAD), namely the income earned by the regions which are collected based on regional regulations in accordance with statutory regulations. PAD aims to give authority to Regional Governments to fund the implementation of regional autonomy in accordance with regional potential as a manifestation of decentralization.

One type of local tax that can be collected by the district/city government in accordance with Article 2 paragraph (2) letter g of Law Number 28 of 2009 concerning local taxe and local retribution are parking tax.

The results of Primary research et al. (2018) show that the parking tax has a positive and significant effect on Padang City's original local revenue (PAD). Therefore, with the increase in local tax sourced from parking taxes, the original local revenue (PAD) will also increase. Therefore, the hypothesis proposed is

Hypothesis 2: It is suspected that hotel parking tax receipts partially affect the original local revenue (PAD) of Pandeglang Regency 2015-2019

\section{The Effect of Hotel Tax Revenue and Parking Tax on Original Local Revenue (PAD)}

Revenues that are sufficient to contribute to regional revenues are hotel taxes and parking taxes; regions, namely districts or cities, are said to be successful regions, which can reflect higher original local revenue (PAD). So the hotel tax and parking tax have a significant effect on PAD. The higher the hotel tax and parking tax, the higher the PAD that will be received by the government, and vice versa, the lower the hotel tax and parking tax, the lower the PAD value that will be received by the local government. . According to Vadia Vamiagustin: 2014 there is a simultaneous effect on the variable hotel tax and parking tax on the PAD variable.

Therefore, the hypothesis proposed is

Hypothesis 3: It is suspected that hotel tax receipts and parking taxes simultaneously affect the original local revenue (PAD) of Pandeglang Regency 2015-2019

\section{METHOD}

The following is a description of the framework of thinking in this research as follows:

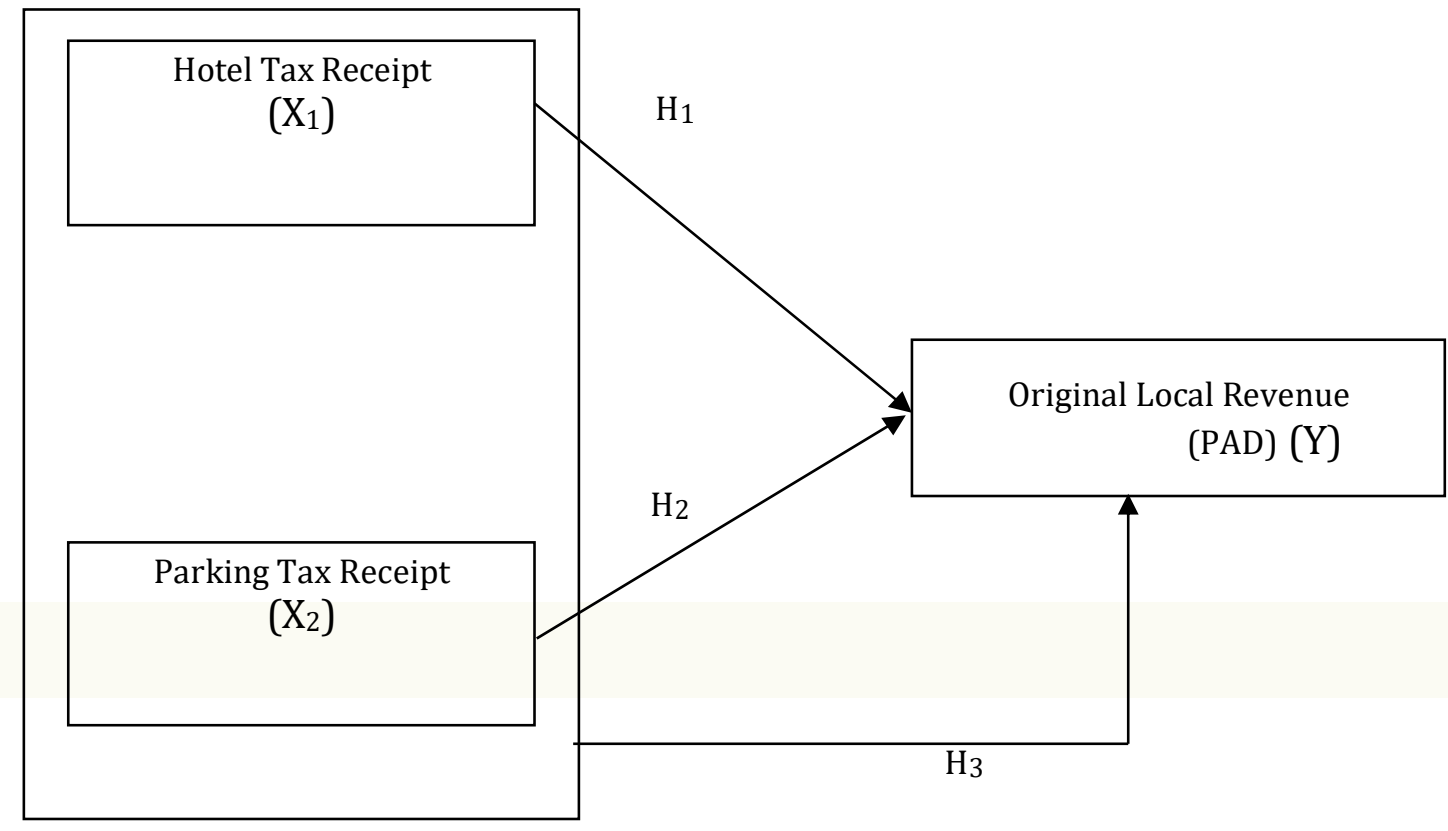

Figure 1. Theoretical Framework

Source: processed data (2021) 
Original local revenue (PAD) is all local government revenues sourced from the results of the original economy in the area. In regional income, the source of income consists of original local revenue (PAD), hereinafter referred to as original local revenue (PAD), namely local taxe results, regional distribution results, separated regional wealth management results, and other legitimate PAD, balancing funds, and so on. -Other legitimate regional income.

This phenomenon shows that the importance of taxes for a region, especially in supporting regional development itself, is a very potent source of income because the amount of tax revenue will increase along with the rate of population growth, economy, and political stability. In the development of a region, taxes play an important role in development, including hotel and parking taxes.

As one of the potential sources of the regional revenue, the growth of hotel tax revenues greatly affects the amount of realized tax received compared to the target set by the Regional Finance Agency for each month, because if the greater the realization that can be obtained, the growth of tax revenue will also increase. In the Region and vice versa, if it does not reach the target, it can be indicated that the tax collection process is not optimal (Suha \& Wahyudi, 2018).

So, in this case, the Pandeglang Regency government really needs to optimize the collection of parking taxes. There are many ways that local governments can use to optimize original local revenue (PAD) through the Parking Tax, such as capturing illegal parking actors and providers. Maybe without us realizing it, we often or maybe even always use illegal parking services, such as parking lots that charge a service fee for providing parking spaces but do not provide parking tickets at all. We should suspect it because if the place is legal, then the parking ticket is the most basic thing to prove the number of service users which will later be reported to the government. After that, the next government must simplify the parking tax registration and reporting system and provide a deterrent effect on those who violate the procedures for providing illegal parking services by taking firm action against those who violate these rules.Penelitian dilaksanakan di Pandeglang Regency Local Tax Service Agency (BP2D).

The population in this study is the Pandeglang Regency budget report for five years in the 2015-2019 period. In this study, the author uses a saturated sampling technique, which is a sampling technique when all members of the population are used as samples so that the model used in this study is five years of Pandeglang Regency's financial statements with an observation period of 2016-2020. This research was designed using a quantitative research approach. Quantitative research methods can be interpreted as research methods based on the philosophy of positivism, used to examine certain populations or samples, sampling techniques are generally carried out randomly, data collection uses research instruments, data analysis is quantitative/statistical with the aim of testing hypotheses. Set.

The data collection technique used is secondary data, which is data collected indirectly, which is obtained by utilizing the results of data collected from other parties, for example, profiles, data on financial statements of companies that have gone public, data from the Central Statistics Agency, and medical records and tertiary data is data collected and obtained from scientific journals and magazines. 
Operational variables in this study are:

Tabel 2. Variable Operation

\begin{tabular}{|c|c|c|c|}
\hline No & $\begin{array}{l}\text { Operational } \\
\text { definition }\end{array}$ & Indicator & $\begin{array}{c}\text { Scale } \\
\text { Measurement }\end{array}$ \\
\hline 1 & $\begin{array}{l}\text { Original local revenue (PAD) is all } \\
\text { revenues obtained by the Region } \\
\text { from sources within its territory } \\
\text { which are collected based on regional } \\
\text { regulations in accordance with } \\
\text { applicable laws and regulations. The } \\
\text { provincial income sector plays a } \\
\text { significant role because through this } \\
\text { sector; it can be seen to what extent a } \\
\text { region can finance government } \\
\text { activities and regional development } \\
\text { (Phaureula Artha Wulandari dan } \\
\text { Iryanie Emy, 2017) }\end{array}$ & $\begin{array}{ll}\text { a. } & \text { Local tax } \\
\text { b. } & \text { Local } \\
\text { retribution } \\
\text { c. }\end{array}$ & Nominal \\
\hline 2 & $\begin{array}{l}\text { Hotel tax is a tax levied on services } \\
\text { provided by hotels, including } \\
\text { supporting services as a complete } \\
\text { hotel for convenience, including } \\
\text { sports and entertainment } \\
\text { facilities.(Irwan, 2015) }\end{array}$ & $\begin{array}{l}\text { Hotel tax receipts } \\
\text { (Empathy) }\end{array}$ & Nominal \\
\hline 3 & $\begin{array}{l}\text { Parking tax is a tax levied on the } \\
\text { operation of parking spaces outside } \\
\text { the body, whether provided in } \\
\text { connection with the main business or } \\
\text { provided as a business, including the } \\
\text { provision of motorized vehicle } \\
\text { storage and motor vehicle guarantees } \\
\text { that charge a fee.(Samudra, 2015) }\end{array}$ & Parking tax receipt & Nominal \\
\hline
\end{tabular}

Source: processed data (2021)

\section{Data Analysis Techniques \\ Multiple Regression Analysis}

To measure the influence between the independent variable and the dependent variable using the multiple regression analysis method. The formula used is:

$$
\bar{Y}=\mathrm{a}+\mathrm{b}_{1} \mathrm{X}_{1}+\mathrm{b}_{2} \mathrm{X}_{2}+\mathrm{e}
$$

Information :

$\mathrm{Y}=$ dependent variable

$\mathrm{a}=$ Constant

$\mathrm{X} 1$ = Independent variable 1

$\mathrm{X} 2$ = Independent variable 2

b1 $=$ Regression Coefficient

b2 = Regression Coefficient 


\section{Coefficient of Determination Analysis}

To determine the level of influence between the variables $\mathrm{X}$ to $\mathrm{Y}$ can be known more clearly by using the coefficient of determination formula as follows:

Where:

$$
\mathrm{Kd}=\mathrm{r}^{2} \times 100 \%
$$

$\mathrm{Kd}=$ Coefficient of Determination

$\mathrm{r}=$ Correlation coefficient

After calculating or analyzing each variable, then the correlation between the two variables is carried out, namely to find out the extent of the correlation between the $\mathrm{X}$ variable and the $\mathrm{Y}$ variable.(Sugiyono, 2014)

\section{Rancangan Uji Hipotesis}

1. Hypothesis $1(\mathrm{H} 1)$

$\mathrm{H}_{0}: \beta 1=0 \rightarrow$ There is no effect of hotel tax revenue on original local revenue (PAD) in regencies and cities throughout Banten Province for the Period 2015-2019

$\mathrm{H}_{\mathrm{a}}: \beta \neq 0 \rightarrow$ There is an effect of hotel tax revenue on original local revenue (PAD) in Regencies and Cities throughout Banten Province for the Period 2015-2019

2. Hipotesis $2\left(\mathrm{H}_{2}\right)$

$\mathrm{H} 0: \beta 1=0 \rightarrow$ There is no effect of parking tax receipts on original local revenue (PAD) (PAD) in regencies and cities throughout Banten Province for the Period 20152019

$\mathrm{Ha}: \beta \neq 0 \rightarrow$ There is an effect of parking tax receipts on Original Local Revenue (PAD) (PAD) in Regencies and Cities throughout Banten Province for the Period 2015-2019

3. Hypothesis 3

$\mathrm{H} 0: \beta 1=\beta 2=0 \rightarrow$ There is no effect of hotel tax receipts and parking tax receipts together on Original Local Revenue (PAD) in Regencies and Cities in Banten Province for the Period 2015-2019

$\mathrm{H}_{\mathrm{a}}: \beta 1 \neq \beta 2 \neq 0 \rightarrow$ There is an effect of hotel tax receipts and parking tax receipts together on original local revenue (PAD) in Regencies and Cities throughout Banten Province for the Period 2015-2019

\section{RESULTS AND DISCUSSION}

Original local revenue (PAD) is all revenues obtained by the Region from sources within its territory which are collected based on regional regulations following applicable laws and regulations. The provincial income sector plays a significant role because through this sector; it can be seen how far a region can finance government activities and regional development. The following is the original local revenue (PAD) at Pandeglang Regency 2015-2019: 
Tabel 3. Data original local revenue (PAD) Pandeglang Regency Period 2015-2019 in rupiah

\begin{tabular}{ccccc}
\hline No & Tahun & Target & Realization & \% \\
\hline 1 & 2015 & $152,738,318,922.38$ & $163,921,272,579.00$ & $107.32 \%$ \\
2 & 2016 & $193,616,153,452.39$ & $198,750,877,114.00$ & $102.65 \%$ \\
3 & 2017 & $197,558,601,652.39$ & $235,085,034,494.00$ & $119.00 \%$ \\
4 & 2018 & $205,646,028,714.00$ & $196,996,806,997.25$ & $95.79 \%$ \\
5 & 2019 & $229,068,192,270.00$ & $218,326,857,973.91$ & $95.31 \%$ \\
\hline
\end{tabular}

Source: processed data (2021)

Based on the table above, the original local revenue (PAD) of Pandeglang Regency 2015-2019 fluctuated in the 2015-2019 period, for the last five years, the lowest PAD revenue was obtained in 2015, which was Rp. 163,921,272,579.00, while the highest PAD was obtained in 2017 which was Rp. Rp. 235,085,034,494.00. In 2018 Pandeglang Regency's PAD experienced a decline, this was due to the lack of regional sensitivity in discovering the advantages of local culture and potential, relatively low compliance and awareness of taxpayers or retribution, weak legal and administrative systems of regional income, and often the expenditures used to run the program is marked up from the start on each budget.

Parking tax is a tax imposed on the operation of parking spaces outside the body, whether provided in connection with the main business or provided as a business, including the provision of motorized vehicle storage and motor vehicle guarantees that charge a fee.

The following is the parking tax data at Pandeglang Regency 2015-2019:

Tabel 4. Pandeglang Regency Parking Tax Data 2015-2019 Period in rupiah

\begin{tabular}{ccrrc}
\hline No & Year & \multicolumn{1}{c}{ Target } & Realization & \% \\
\hline 1 & 2015 & $50,750,000.00$ & $56,295,437.00$ & $110.93 \%$ \\
2 & 2016 & $55,000,000.00$ & $41,491,434.00$ & $75.44 \%$ \\
3 & 2017 & $55,556,700.00$ & $52,788,455.00$ & $95.02 \%$ \\
4 & 2018 & $100,500,000.00$ & $77,553,697.00$ & $77.17 \%$ \\
5 & 2019 & $146,886,338.00$ & $83,799,121.00$ & $57.05 \%$ \\
\hline
\end{tabular}

Source: processed data (2021)

Based on the table above, the 2015-2019 Pandeglang Regency parking tax revenue fluctuated. The highest parking tax revenue was obtained by the Serang Regency in 2019 of Rp. 83,799,121.00 while the lowest parking tax revenue in 2016 was Rp. 41,491,434.00; the higher the parking tax revenue, the more significant the contribution to PAD.

The object of hotel tax is the service provided by the hotel with payment, including supporting services as the completeness of the hotel that provides convenience and comfort, including sports and entertainment facilities. boarding houses, guesthouses, tourist lodges, and meeting halls

The following is the data on hotel tax receipts at Pandeglang Regency 2015-2019:

Tabel 5. Pandeglang Regency Hotel Tax Revenue Data 2015-2019 Period in rupiah

\begin{tabular}{ccccc} 
No & Year & Target & Realization & $\%$ \\
\hline 1 & 2015 & $2,297,500,000.00$ & $3,052,585,977.00$ & $132.87 \%$ \\
2 & 2016 & $3,332,500,000.00$ & $3,245,162,780.00$ & $97.38 \%$
\end{tabular}


THE EFFECT OF POST TSUNAMI HOTEL TAX RECEIVING AND PARKING TAX ON ORIGINAL LOCAL REVENUE (PAD) PANDEGLANG REGENCY PERIOD 2015-2019

\begin{tabular}{ccccc}
\hline 3 & 2017 & $3,350,213,902.00$ & $3,575,068,943.00$ & $106.71 \%$ \\
4 & 2018 & $3,915,367,440.00$ & $3,495,778,095.00$ & $89.28 \%$ \\
5 & 2019 & $1,120,200,000.00$ & $1,167,855,149.00$ & $104.25 \%$ \\
\hline
\end{tabular}

Source: processed data (2021)

Based on the table above, Pandeglang Regency 2015-2019 hotel tax revenues fluctuated. The highest hotel tax revenue was obtained in 2017 of Rp. 3,575,068,943.00 while the lowest hotel tax revenue in 2019 was $1,167,855,149.00$, the higher the hotel tax revenue, the greater the contribution to PAD.

\section{Multiple Linear Regression Test}

To measure the effect of hotel tax revenue and parking tax on original local revenue (PAD) using the multiple regression analysis methods is as follows:

Tabel 6. Multiple Linear Regression Test

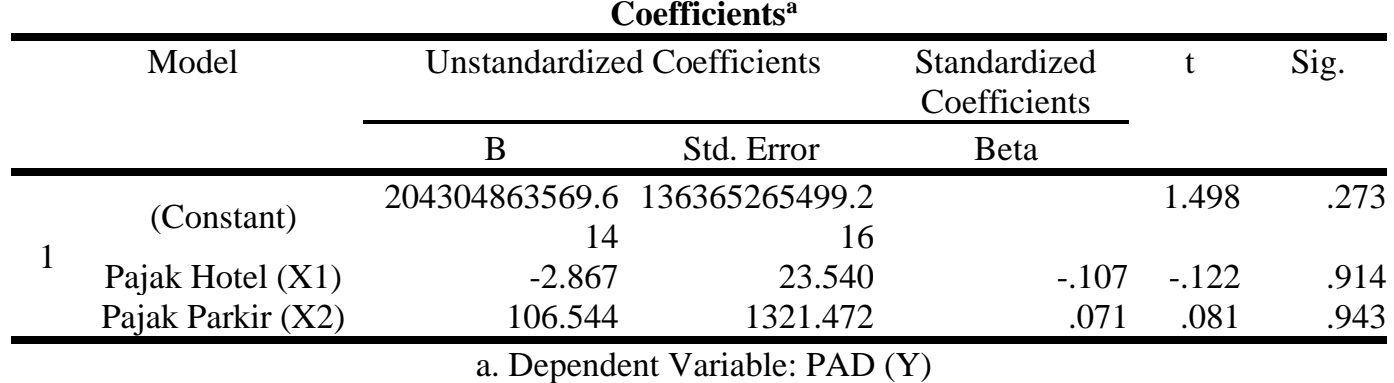

Source: processed data (2021)

Based on the table above, the following equation can be formed:

$$
\widehat{Y}=204304863569.614-2.867 . \mathrm{X}_{1}+106.544 . \mathrm{X}_{2}+\mathrm{e}
$$

The regression line equation obtained, then the regression model can be interpreted as follows:

1. The price of the constant coefficient of 204304863569.614 shows that the hotel tax revenue and parking tax variable if the value is 0 , then the original local revenue (PAD) has a level of 204304863569.614

2. The price coefficient $\mathrm{b} 1=-0.122$ (negative) means that if the value of $\mathrm{X} 1$ (hotel tax revenue) has decreased by 1 unit, while other independent variables are fixed, the level of the original local revenue (PAD) variable will reduce by 2,867 .

3. The price of the coefficient $\mathrm{b} 2=106,544$ if the value of $\mathrm{X} 2$ (parking tax) has increased by 1 unit, while the other independent variables are fixed, then the level of the original local revenue (PAD) variable will increase by 106,544 .

\section{Coefficient of Determination Test}

The coefficient of determination shows how many percent of the variation (up and down) the dependent variable can be explained or explained by the variation of the independent variable, the coefficient of determination of hotel tax revenue (X1) and parking tax (X2) on original local revenue (PAD) (Y) is as follows: 
Tabel 7. Coefficient of Determination

Model Summary ${ }^{\mathrm{b}}$

\begin{tabular}{ccccc}
\hline Model & R & R Square & $\begin{array}{c}\text { Adjusted R } \\
\text { Square }\end{array}$ & $\begin{array}{c}\text { Std. Error of the } \\
\text { Estimate }\end{array}$ \\
\hline 1 & $.160^{\mathrm{a}}$ & .026 & -.949 & 37229414500.33 \\
& & & 514 \\
\hline \multicolumn{2}{c}{ a. Predictors: (Constant), Pajak Parkir (X2), Pajak Hotel (X1) } \\
b. Dependent Variable: PAD (Y)
\end{tabular}

Source: processed data (2021)

Based on the table above, the coefficient of determination (R2) R Square is 0.026 . This can be interpreted that the variable hotel tax revenue and parking tax affect $2.6 \%$ of the original local revenue (PAD), and the remaining $97.4 \%$ is influenced by other factors not examined in this study.

\section{Hypothesis test}

This test is used to determine whether the independent variables partially or individually affect the dependent variable. Decision-making is based on the tcount of each regression coefficient with the table value in accordance with the significant level used of $5 \%$.

\section{Effect of hotel tax revenue (X1) on original local revenue (PAD) (Y)}

To test the effect of whether the hypothesis that was originally set was accepted or

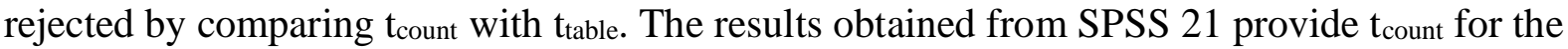
variable hotel tax revenue (X1) against original local revenue (PAD) (Y) in the table below:

Tabel 8. Results of t-test of Hypothesis 1

\begin{tabular}{|c|c|c|c|c|c|c|}
\hline \multicolumn{7}{|c|}{ Coefficients $^{\mathrm{a}}$} \\
\hline \multirow{2}{*}{\multicolumn{2}{|c|}{ Model }} & \multicolumn{2}{|c|}{ Unstandardized Coefficients } & \multirow{2}{*}{$\begin{array}{c}\begin{array}{c}\text { Standardized } \\
\text { Coefficients }\end{array} \\
\text { Beta }\end{array}$} & \multirow[t]{2}{*}{$\mathrm{t}$} & \multirow[t]{2}{*}{ Sig. } \\
\hline & & $\mathrm{B}$ & Std. Error & & & \\
\hline \multirow{3}{*}{1} & (Constant) & $\begin{array}{r}204304863569.6 \\
14\end{array}$ & $\begin{array}{r}136365265499.2 \\
16\end{array}$ & & 1.498 & .273 \\
\hline & Hotel Tax (X1) & -2.867 & 23.540 & -.107 & -.122 & .914 \\
\hline & Parking Tax (X2) & 106.544 & 1321.472 & .071 & .081 & .943 \\
\hline
\end{tabular}

Source: processed data (2021)

Based on the table above, it is obtained that $t_{\text {count }}$ is 0.006 and $t_{\text {table }}$ is Degrees of Freedom $(\mathrm{dk})=\mathrm{n}-2(5-2=3)$ then obtained table of 3.182 , the results are $\mathrm{t}_{\text {count }}<\mathrm{t}$ table $(-0.122$ $<3.182$ ) with a significance level of $0.914>00.05(5 \%)$ it can be concluded that there is no effect of hotel tax revenue on original local revenue (PAD) at Pandeglang Regency 20152019.

\section{Effect of Parking Tax (X2) on original local revenue (PAD) (Y)}

To test the effect of whether the hypothesis that was originally set was accepted or rejected by comparing tcount with table. The results obtained from SPSS 21 provide $t_{\text {count }}$ for the variable parking tax (X2) against original local revenue (PAD) (Y) in the table below: 
THE EFFECT OF POST TSUNAMI HOTEL TAX RECEIVING AND PARKING TAX ON ORIGINAL LOCAL REVENUE (PAD) PANDEGLANG REGENCY PERIOD 2015-2019

(Pratiwi and Wahyudi)

Tabel 9. Hypothesis 2 t-test results

\begin{tabular}{|c|c|c|c|c|c|c|}
\hline \multicolumn{7}{|c|}{ Coefficients $^{\mathrm{a}}$} \\
\hline & \multirow[t]{2}{*}{ Model } & \multicolumn{2}{|c|}{ Unstandardized Coefficients } & \multirow{2}{*}{$\begin{array}{l}\text { Standardized } \\
\text { Coefficients } \\
\text { Beta }\end{array}$} & \multirow[t]{2}{*}{$\mathrm{t}$} & \multirow[t]{2}{*}{ Sig. } \\
\hline & & B & Std. Error & & & \\
\hline \multirow{3}{*}{1} & (Constant) & $\begin{array}{r}204304863569.6 \\
14\end{array}$ & $\begin{array}{r}136365265499.2 \\
16\end{array}$ & & 1.498 & .273 \\
\hline & Hotel Tax (X1) & -2.867 & 23.540 & -.107 & -.122 & .914 \\
\hline & Parking Tax (X2) & 106.544 & 1321.472 & .071 & .081 & 943 \\
\hline
\end{tabular}

Source: processed data (2021)

Based on the table above, it is obtained that $t_{\text {count }}$ is -0.678 and $t_{\text {table }}$ is Degrees of Freedom $(\mathrm{dk})=\mathrm{n}-2(5-2=3)$, so that ttable is 3.182 , the results are $\mathrm{t}_{\text {count }}<$ table $(0.081<$ $3.182)$ with a significance level of $0.943>00.05(5 \%)$ it can be concluded that there is no effect of parking tax revenue on original local revenue (PAD) at Pandeglang Regency 20152019.

This test is used to determine whether the independent variables simultaneously or jointly affect the dependent variable. Decision making is based on $\mathrm{F}_{\text {count }}$ of each regression coefficient with a value of table in accordance with the significant level used at $5 \%$

In the $\mathrm{F}$ test to prove whether the Hotel Tax Revenue (X1) and Parking Tax (X2) variables simultaneously have an effect on original local revenue (PAD) (Y), the F test is carried out as follows:

Tabel 5. F Test Results (Hypothesis 3)

\begin{tabular}{|c|c|c|c|c|c|c|c|}
\hline \multicolumn{7}{|c|}{ ANOVA $^{\mathrm{a}}$} & Sig. \\
\hline & Regression & 72807086140714910000.000 & & 2 & $\begin{array}{r}36403543070357455 \\
000.000\end{array}$ & .026 & $.974^{\mathrm{b}}$ \\
\hline 1 & Residual & $\begin{array}{r}2772058608075529500000.0 \\
00\end{array}$ & & 2 & $\begin{array}{r}13860293040377648 \\
00000.000\end{array}$ & & \\
\hline & Total & $\begin{array}{r}2844865694216244700000.0 \\
00\end{array}$ & & 4 & & & \\
\hline
\end{tabular}

a. Dependent Variable: PAD (Y)

b. Predictors: (Constant), Pajak Parkir (X2), Pajak Hotel (X1)

Source: processed data (2021)

Based on the table above, it is obtained that $\mathrm{F}_{\text {count }}=0.026$ while the value of $\mathrm{F}_{\text {table }}(\mathrm{dk}=$ $\mathrm{n}-\mathrm{k}-1=5-2-1=2)$ is 19,000 with a significance level of $0.974>0.05(5 \%)$ so that $\mathrm{F}_{\text {count }}>$ Ftable $(0.026<19,000)$ so that it is simultaneously generated that there is no effect of hotel tax revenue and parking tax simultaneously on original local revenue (PAD) at Pandeglang Regency 2015-2019.

\section{Discussion of Research Results \\ Effect of Hotel Tax Revenue (X1) on original local revenue (PAD) (Y)}

In the research hypothesis, it is suspected that hotel tax revenue partially affects original local revenue (PAD) at Pandeglang Regency 2015-2019, the calculation results obtained tcount is -0.122 and table is Degree of Freedom $(\mathrm{dk})=\mathrm{n}-2(5-2=3)$ then obtained table of 3.182, the results of $t_{\text {count }}<t_{\text {table }}(-0.122<3.182)$ with a significance level of $0.914>0.05$ $(5 \%)$ it can be concluded that there is no effect of hotel tax revenue on original local revenue (PAD) at Pandeglang Regency 2015- 2019.

The absence of the effect of hotel taxes on original local revenue (PAD) is caused by the decreasing number of visitors to lodging/hotels in Banten Province in general, especially 
in places where there are many tourist sites that require lodging/tourism service facilities resulting in the period 2018-2019 Province. Banten was affected by the Tsunami, so that the hotel tax sector could not affect the original local revenue (PAD). In addition, there are obstacles from the collection system applied to the restaurant tax itself, namely the collection uses a self-assessment system where the tax calculations are carried out by their own calculations, and it takes the honesty of the taxpayer in reporting their turnover so that this results in taxpayers committing fraud due to weak supervision of the taxpayer Revenue officer.

Hotel tax as a potential source of regional revenue must be managed optimally. Pandeglang Regency's original local revenue (PAD) for the 2015-2019 period hotel tax revenue has not been able to contribute to increasing original local revenue (PAD), this means that several areas in Banten Province were affected by the Tsunami so that the hotel business experienced a decrease in revenue.

The results of this study are not supported by (Wahyuni dan Utara, 2018), (Widodo \& Guritno, 2017), and (Aznedra, 2017) the results of the study show that hotel tax has a significant effect on original local revenue (PAD).

\section{Effect of Parking Tax (X2) on original local revenue (PAD) (Y)}

In the research hypothesis, it is suspected that parking taxes partially affect original local revenue (PAD) at Pandeglang Regency 2015-2019, obtained tcount of 0.081 and table is Degrees of Freedom $(\mathrm{dk})=\mathrm{n}-2(5-2=3)$ then obtained table of 3,182 the results obtained $\mathrm{t}_{\text {count }}$ $<t_{\text {table }}(0.081<3.182)$ with a significance level of $0.943>0.05(5 \%)$ so it can be concluded that there is no effect of parking tax revenue on original local revenue (PAD) at Pandeglang Regency 2015-2019.

Parking tax is an essential source of regional income to finance the implementation of development and local government. The effectiveness of the parking tax on original local revenue (PAD) is said to be effective if the minimum realization meets the targets set each year and meets the effectiveness criteria. In supporting the smooth running of government and regional development, one of the sources of regional income comes from local tax revenues, one of which is from the parking tax sector.

The contribution of parking taxes to the original local revenue (PAD) of Pandeglang Regency for the 2015-2019 period has not been able to contribute to increasing original local revenue (PAD), this means that there is a decrease in the business of organizing off-street parking lots, both provided related to the central business as well as those provided as a business, including the provision of motorized vehicle storage and the provision of free parking spaces as a form of service to its customers.

This research is not supported by the research of (Makur, 2020) and (Pratama et al., 2017), which states that the results of his research on parking taxes have an influence on the dependent variable, namely original local revenue (PAD).

\section{Effect of Hotel Tax Revenue (X1) and Parking Tax (X2) on original local revenue (PAD)} (Y)

The research hypothesis is suspected that hotel tax revenues and parking taxes simultaneously affect original local revenue (PAD) at Pandeglang Regency 2015-2019. The test results obtained Fcount $=0.026$ while the value of Ftable $(\mathrm{dk}=\mathrm{n}-\mathrm{k}-1=5-2-1=2)$ is 19,000 with a significance level of $0.974>0.05(5 \%)$ so that $F_{\text {count }}>F_{\text {table }}(0.026<19,000)$ so that it is simultaneously generated that there is no effect of hotel tax receipts and parking taxes simultaneously on original local revenue (PAD) at Pandeglang Regency 2015-2019.

The contribution of hotel taxes and parking taxes to Pandeglang Regency's original local revenue (PAD) for the 2015-2019 period has not been able to increase original local 
revenue (PAD) because several tourist attractions provide hotel services and parking lots mostly experience problems. decrease in income, even though it has good potential to increase tax revenue to increase original local revenue (PAD)

\section{CONCLUSION}

Based on the results of the analysis and discussion on the effect of hotel tax revenue and parking tax on original local revenue (PAD), the authors draw the following conclusions:

1. There is no effect of hotel tax revenue on original local revenue (PAD) at Pandeglang Regency 2015-2019

2. There is no effect of parking tax revenue on original local revenue (PAD) at Pandeglang Regency 2015-2019

3. There is no effect of simultaneous hotel tax revenue and parking tax on original local revenue (PAD) at Pandeglang Regency 2015-2019.

Based on the conclusions above, the implications can be stated as follows:

1. Hotel tax revenue has no effect on original local revenue (PAD); this means that hotel tax does not contribute to original local revenue (PAD). Hotel tax revenues have not been able to contribute to increasing original local revenue (PAD); this means that the Pandeglang Regency area in the tourism sector was affected by the Tsunami so that the hotel business experienced a decrease in revenue.

2. Parking tax has no effect on original local revenue (PAD), the contribution of parking tax to original local revenue (PAD) Pandeglang Regency for the 2015-2019 period has not been able to contribute to increasing original local revenue (PAD), this means there is a decrease the business of organizing off-street parking spaces, whether provided in connection with the main business or provided as a business, including the provision of motorized vehicle storage areas and the provision of free parking spaces as a form of service to its customers.

\section{REFERENCES}

Alisman. (2015). Analisis Faktor-Faktor yang Mempengaruhi Penerimaan Pajak Hotel di Kabupaten Aceh Barat. Jurnal Ekonomi Dan Kebijakan Publik Indonesia, 2(3), 53944.e2.

Aznedra, A. (2017). Pengaruh Kontribusi Penerimaan Pajak Hotel Dan Pajak Restoran Terhadap Pendapatan Asli Daerah Di Wilayah Kota Batam Tahun 2012-2014 (Studi Kasus Dinas Pendapatan Asli Daerah di Kota Batam). Jurnal Dimensi, 6(2), 235-255

Irwan, W. (2015). Pajak Di Beragam Sektor Usaha (1st ed., p. 16). Indeks Jakarta.

Pandiangan, Liberti. 2014. Administrasi Perpajakan. Jakarta: PT Elek Media Komputindo

Makur, D. (2020). Pengaruh Pajak Parkir Terhadap Pendapatan Asli Daerah Kota Gorontalo. Journal Syariah and Accounting Public, 27-33.

Phaureula Artha Wulandari dan Iryanie Emy. (2017). Pajak Daerah dalam Pendapatan Asli Daerah (Cetakan pe, p. 98 halaman). Yogyakarta.

Pratama, R., Sudarmanto, E., \& Timuriana, T. (2017). Pendapatan Asli Daerah Kota Bogor. Jurnal Online Mahasiswa (JOM) Bidang Akuntansi, 5.

Puspitasari, R. A., Wilopo, \& Prasetya, A. (2016). Peran Pemungutan Pajak Parkir dalam 
Peningkatan Pendapatan Asli Daerah di Kota Malang (Studi Kasus pada Dinas Pendapatan Daerah Kota Malang). Jurnal Mahasiswa Perpajakan, 8(1), 1-6.

Samudra, A. A. (2015). Perpajakan Di Indonesia :Keuangan, Pajak, dan Retribusi Daerah (Ed. 1, cet, pp. xx, 326 hlm ;23 cm). Jakarta : Rajawali Pers, 2016.

Sugiyono. (2014). Statistika Untuk Penelitian (Cetakan 19). Bandung : Alfabeta.

Wahyuni dan Utara. (2018). Pengaruh Penerimaan Pajak Hotel dan Pajak Restoran Terhadap Pendapatan Asli Daerah (PAD) pada Badan Pengelolaan Pajak dan Retribusi Daerah Kota Medan. EKONOMIKAWAN: Jurnal Ilmu Ekonomi Dan Studi Pembangunan, $18(1), 1-11$.

Widodo, W. I., \& Guritno, B. (2017). Pengaruh Pajak Hotel, Pajak Restauran Dan Pajak Hiburan Terhadap Pendapatan Asli Daerah (PAD) Di Kota Yogyakarta. Junal Visi Manajemen, 2(2), 128-138. 